\title{
Characterization of bacterial population during composting of municipal solid waste
}

\author{
Caracterização da população bacteriana em processo de compostagem de resíduos urbanos \\ Diego Hoffmeister ${ }^{1}$, José Carlos Germani² \& Sueli Teresinha Van Der Sand ${ }^{1}$
}

\begin{abstract}
Composting is a natural biological process that degrades organic matter which is carried out spontaneously by aerobic microorganisms, whose metabolic action leads to the mineralization and partial humification of organic residue. The aim of this study was to investigate survival of potentially pathogenic bacterial species throughout the process and detection of enterotoxigenic Escherichia coli (ETEC) in the compost using PCR. The presence of heterotrophic bacteria, total total and fecal coliforms, and bacteria succession were also determined. Out of the total 222 bacterial colonies isolated, 33 different genera and 56 different species were identified, being Bacillus, Escherichia, Enterobacter, and Pseudomonas, the prevailing genera. Total coliform counts ranged between $9.0 \times 10^{4}$ and $3.0 \times 10^{6} \mathrm{cfu} / \mathrm{g}$, and fecal coliform counts between $1.0 \times 10^{4}$ and $2.3 \times 10^{6} \mathrm{cfu} / \mathrm{g}$. The composting process was partially efficient, since even though coliform counts were reduced, enterotoxigenic $E$. coli was detected in mature compost.
\end{abstract}

Key words: Composting, bacterial population, solid waste, enterotoxigenic Escherichia coli (ETEC), PCR.

\section{RESUMO}

Compostagem é um processo biológico natural de degradação da matéria orgânica, desenvolvida espontaneamente por microrganismos cuja atividade metabólica leva a mineralização e humificação parcial da matéria orgânica. O objetivo deste estudo foi investigar a sobrevivência de espécies bacterianas potencialmente patogênicas durante o processo de compostagem e a detecção de Escherichia coli enterotoxigênica (ETEC) do composto usando PCR. A presença de bactérias heterotróficas, coliformes totais e fecais e a sucessão da população bacteriana durante a compostagem foi determinada. Do total de 222 colônias bacterianas isoladas 33 gêneros e 56 espécies foram identificados. Os gêneros predominantes foram Bacillus, Escherichia,

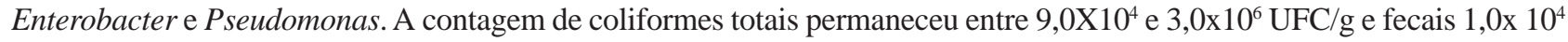
e 2,3x $10^{6} \mathrm{UFC} / \mathrm{g}$. O processo de compostagem apresentou uma eficiência parcial, pois apesar de ter ocorrido uma redução na contagem de coliformes $E$. coli (ETEC) foi detectada no composto final.

Descritores: compostagem, população bacteriana, resíduo sólido, E. coli enterotoxigênica, PCR. 


\section{INTRODUCTION}

Composting is a natural biological process of aerobic decay carried out by a wide range of microorganisms that stabilizes organic matter and generates mulch $[14,29,33]$. Mulch is the end product of this process and it has proved a valuable fertilizer and conditioner of depleted soils [3, 6,13,20,22]. Many factors determine the microbial community during composting, but under aerobic conditions, temperature is the major factor that defines what genera of microorganisms, will be present, species diversity, and rate of metabolic activities [15].

Microbial quality of the compost reflects the effectiveness of the composting process. Therefore, a thorough assessment of maturation is crucial because the use of an under-maturated compost may provoke serious biological damage to soils [11,17,19], along with the proliferation and spreading of potentially pathogenic microorganisms.

Enterotoxigenic E. coli (ETEC) strains are an important cause of diarrhea in infants and adult travellers in the human population. These strains are also responsible for diarrheal diseases of animals such as pig and cattle, and may produce types I and II heatstable (ST) and types I and II heat-labile (LT) toxins. Most diarrhea outbreaks occurring world-wide are due to the consumption of contaminated foods and water [7].

The aim of this study was to investigate the succession of bacterial population and the survival of potentially pathogenic bacteria throughout the composting process adopted in the treatment of municipal solid waste. A PCR technique was used to detect enterotoxigenic Escherichia coli (ETEC) in the end product.

\section{MATERIALS AND METHODS}

\section{Sampling}

Samples were collected from a municipal waste compost windrow, in a solid waste sorting and composting plant in the Greater Porto Alegre, state of Rio Grande do Sul, Brazil. The composting process consisted in forming windrows that underwent forced aeration cycles from under the bottom, for six minutes every hour. Sampling took place fortnightly for 14 weeks, and a subsequent collection happened at full maturation of the compost at the $22^{\text {nd }}$ week. Samples were collected at three different locations and depths in the composting pile (lower, upper and median point) mixed, and one aliquot of $10 \mathrm{~g}$ was used as a sample.

\section{pH determination}

The $\mathrm{pH}$ of each sample was determined using a suspension obtained by dispersing the compost sample in sterile distilled water 1:5 [18].

\section{Microbiologic assays}

A suspension using $10 \mathrm{~g}$ compost sample was prepared in $90 \mathrm{~mL}$ sterile distilled water. This mixture was incubated at $30^{\circ} \mathrm{C}$ at $100 \mathrm{rpm}$ in an orbital shaker for $30 \mathrm{~min}$ to homogenize the sample. Whereupon serial dilutions were prepared and used in microbial counts, colimetric assays and bacteria isolation for identification.

\section{Microbial counts}

The pour plate technique on plate count agar (PCA) determined the total culturable heterotrophic bacteria. Plates were incubated at $37^{\circ} \mathrm{C}$ for $24-48$ hours and the total number was estimated by the average number of colony forming units (CFU) per gram of compost samples. Only plates with 30 to 300 colonies were considered for the counting.

\section{Colimetric assays}

Colimetric analysis was carried out using the multiple-tube fermentation procedure as a Most Probable Number (MPN) index [2].

\section{Bacterial isolates}

Isolation of bacteria was done using seven different culture media, brain-heart infusion agar (BHI), blood base agar supplemented with ovine blood 5\%, cetrimide agar, Pseudomonas agar, eosin-methyleneblue lactose saccharose agar (EMB), xylose-lysinedesoxycholate agar (XLD), xylose-lysine-tergitol 4 $\left(\mathrm{XLT}_{4}\right)$. Aliquots of $0,1 \mathrm{~mL}$ of the last three dilutions were seeded on two plates with each of the media, incubated at $37^{\circ} \mathrm{C}$ for $24-48 \mathrm{~h}$. For the isolation of the Salmonella species, samples were pre-enriched in tetrathionate broth at $43^{\circ} \mathrm{C}$ for $16-18 \mathrm{~h}$. Each dilution provided $0.1-\mathrm{mL}$ aliquots that were seeded in duplicate onto plates containing XLD and $\mathrm{XLT}_{4}$ and incubated at $37^{\circ} \mathrm{C}$ for $24 \mathrm{~h}$. Once incubation was over, 5 squares of $1 \mathrm{~cm}^{2}$ were drawn over the plates and 5 colonies from each square were selected from each plate. Identification of isolates started with the Gram's method and afterwards several biochemical tests, like the oxidation/fermentation test, methyl red/Voges Proskauer assay, starch hydrolysis, citrate and indol reactivity, motility, urease reaction, arginine, lysine and ornitin decarboxylation reaction, and the reaction with diffe- 
rent carbon sources were performed following the literature [16].

\section{Contamination of the compost with enterotoxigenic Escherichia coli (ETEC)} Escherichia coli $\mathrm{LT}^{+} \mathrm{ST}^{+}$(ATCC 11105) culture was prepared in $\mathrm{BHI}$ broth and incubated at $37^{\circ} \mathrm{C}$ until it reached a $3 \times 10^{8}$ cell $/ \mathrm{mL}$ concentration. A dilution of fully mature compost was prepared with $10 \mathrm{~g}$ compost dispersed in $90 \mathrm{~mL}$ sterile distilled water. This dilution provided $10-\mathrm{mL}$ aliquots that were transferred to two 250-mL Erlenmeyer flasks containing $30 \mathrm{~mL}$ BHI broth. Subsequently, one of the Erlenmeyer flasks received $300 \mathrm{~mL}$ of the E. coli culture. The other flask was used as negative control, without the seedling with of the E.coli culture. A third flask containing $30 \mathrm{~mL}$ BHI broth and no compost sample received $300 \mathrm{~mL}$ of the $E$. coli culture and was the positive control. All flasks were then incubated at $37^{\circ} \mathrm{C}$ for 16-18 h. These bacterial growths provided the samples for the DNA extraction and the PCR assays.

\section{DNA extraction}

The method employed to extract plasmid DNA was alkaline lysis described by Sambrook et al. [24] with modifications. From each bacterial growth previously described $6 \mathrm{~mL}$ were retrieved and centrifuged at $15,493 \mathrm{~g}$ for $2 \mathrm{~min}$. The pellet was washed in $1 \mathrm{~mL}$ $1 \mathrm{M} \mathrm{NaCl}$. After centrifugation, $200 \mathrm{~mL}$ of solution I was added (50mM glucose, $25 \mathrm{mM}$ Tris $\mathrm{HCl}, 10 \mathrm{mM}$ EDTA ). The mixture was then homogenised and incubated in ice for $30 \mathrm{~min}$. Next, $400 \mathrm{~mL}$ of solution II was added ( $1 \% \mathrm{SDS}, 0,2 \mathrm{M} \mathrm{NaOH})$, and this mixture was incubated in ice for $15 \mathrm{~min} .300 \mathrm{~mL}$ of solution III (5M potassium acetate, glacial acetic acid) was added, and this final mixture was incubated in ice for 30 min. Centrifugation at $15,000 \mathrm{~g}$ for $15 \mathrm{~min}$ followed. The top aqueous phase was then transferred to a new tube and underwent purification by two consecutive extraction with equal volumes of phenol: chloroform extractions. After another centrifugation at 15,000 g for $10 \mathrm{~min}$, DNA precipitation was promoted by the addition of $0.3 \mathrm{M}$ sodium acetate and $2.5 \mathrm{v}$ ice-cold $100 \%$ ethanol. This mixture was incubated at $-20^{\circ} \mathrm{C}$ for $12 \mathrm{~h}$, centrifuged and the pellet was washed in $70 \%$ ethanol and allowed to dry at room temperature. The DNA was resuspended in $40 \mathrm{~mL}$ TE $(10 \mathrm{mM}$ Tris $\mathrm{HCl}$, $1 \mathrm{mM}$ EDTA).

\section{The PCR amplification}

Primers: Primers ${ }^{1}$ used in the detection of enterotoxigenic E. coli were designed based on the com- plete sequences of the target genes of reference [12,34]. The primers LT10 and LT11 are complementary to the gene encoding the heat-labile enterotoxin and amplifies a 221-bp fragment:

LT10 (5' -CGATGGCAGGCAAAAGAGAA-3') and LT11 (5'-GTTTTCCATACTGATTGCCG-3').

Primers ST10 and ST11 are complementary to the gene encoding the heat-stable enterotoxin and amplifies a 167-bp fragment:

ST10 (5'-GTCTTTTTCACCTTTCGCTC-3') and ST11 (5' -TACAAGCAGGATTACAACAC -3').

PCR reactions took place in $2.5 \mathrm{~mL}$ reaction buffer 1x (100 mM Tris $\mathrm{HCl}, 500 \mathrm{mM} \mathrm{KCl}), 6.25 \mathrm{~mL}$ $10 \mathrm{mM} \mathrm{MgCl}, 1 \mathrm{~mL}$ of a solution of the four deoxynucleotides ( $2.8 \mathrm{mM}$ each), $300 \mathrm{ng}$ bovine serum albumin (BSA), $122 \mathrm{ng}$ primer ST 10, $120 \mathrm{ng}$ primer ST 11, or $30 \mathrm{ng}$ primers LT10 and LT 11, $1 \mathrm{U}$ Taq polymerase, and $30 \mathrm{ng}$ template DNA, to a final volume of $25 \mathrm{~mL}$. Reactions were performed in a thermal cycler ${ }^{2}$, under the following conditions for the ST gene: 35 cycles (45 s at $95^{\circ} \mathrm{C}, 45 \mathrm{~s}$ at $47^{\circ} \mathrm{C}, 90 \mathrm{~s}$ at $72^{\circ} \mathrm{C}$ ); and for the LT gene: 30 cycles $\left(30 \mathrm{~s}\right.$ at $95^{\circ} \mathrm{C}, 30 \mathrm{~s}$ at $60^{\circ} \mathrm{C}, 60 \mathrm{~s}$ at $72^{\circ} \mathrm{C}$ ). The PCR product was electrophoresed in a $1,2 \%$ agarose gel containing Tris acetate EDTA (TAE) and stained with ethidium bromide, and then photographed using a Digital camera ${ }^{3}$.

\section{RESULTS}

\section{pH measurements}

The first two samples had $\mathrm{pH}$ values between 5.0 and 6.0 , due to the excretion of organic acids produced by microbial metabolism. Thereafter, $\mathrm{pH}$ values rose and remained essentially unchanged for the last three samples. The final value (8.0) was slightly alkaline (Table 1).

\section{Number of heterotrophic bacteria}

Total number of heterotrophic bacteria at the first sample collection was 5.6 x $10^{6} \mathrm{cfu} / \mathrm{g}$ compost. This count dwindled during the ensuing collections, but came to rise again in the $8^{\text {th }}$ week of composting, reaching $8.0 \times 10^{7}$ at the end of the process (Table 2).

\section{Coliform counts}

Total coliform count fluctuated all through this experiment (Table 2), but a trend downwards was observed as compost maturated, though without an integral elimination of either total or fecal coliform. The data for fecal coliforms demonstrate a significant de- 
Table 1. $\mathrm{pH}$ values for samples collected in municipal waste compost windrows.

\begin{tabular}{ccc}
\hline $\begin{array}{c}\text { Sample } \\
\text { collection }\end{array}$ & $\begin{array}{c}\text { Time of } \\
\text { composting }\end{array}$ & pH \\
\hline 1 & First day & 5,0 \\
2 & 15 days & 6,0 \\
3 & 30 days & 7,0 \\
4 & 45 days & 7,0 \\
5 & 60 days & 8,0 \\
6 & 75 days & 9,0 \\
7 & 90 days & 8,5 \\
8 & 105 days & 8,0 \\
9 & 154 days & 8,0 \\
\hline
\end{tabular}

Table 2. Evolution in heterotrophic microorganisms counts and of the fecal and total coliform counts per gram of solid compost, measured throughout the composting process.

\begin{tabular}{cccc}
\hline Sample & $\begin{array}{c}\text { Heterotrophic } \\
\text { count cells/g }\end{array}$ & $\begin{array}{c}\text { Total coliform } \\
\text { count cells } / \mathbf{g}\end{array}$ & $\begin{array}{c}\text { Fecal coliform } \\
\text { count cells/g }\end{array}$ \\
\hline 1 & $5,6 \times 10^{6}$ & $3,0 \times 10^{6}$ & $2,3 \times 10^{6}$ \\
2 & $8,0 \times 10^{5}$ & $2,3 \times 10^{5}$ & $2,0 \times 10^{4}$ \\
3 & $2,3 \times 10^{6}$ & $5,0 \times 10^{5}$ & $4,0 \times 10^{4}$ \\
4 & $1,17 \times 10^{7}$ & $3,0 \times 10^{5}$ & $1,3 \times 10^{5}$ \\
5 & $1,4 \times 10^{6}$ & $3,0 \times 10^{5}$ & $2,0 \times 10^{4}$ \\
6 & $4,80 \times 10^{7}$ & $3,6 \times 10^{5}$ & $4,0 \times 10^{4}$ \\
7 & $1,20 \times 10^{7}$ & $2,3 \times 10^{5}$ & $4,0 \times 10^{4}$ \\
8 & $5,40 \times 10^{7}$ & $5,0 \times 10^{4}$ & $2,6 \times 10^{4}$ \\
9 & $8,00 \times 10^{7}$ & $9,0 \times 10^{4}$ & $1,0 \times 10^{4}$ \\
\hline
\end{tabular}

crease in cells/g of compost for this group of microorganisms: $2.3 \times 10^{6}$ to $1.1 \times 10^{4}$ cells $/ g$

\section{Biochemical identification of microorganisms}

Results showed a great bacterial diversity throughout the process. Out of the 222 colonies isolated, 33 genera and 56 species were identified. The most commonly detected genera were: Bacillus (19.36\%), Escherichia (14.86\%), Enterobacter (14.41\%), and Pseudomonas (10.36\%), which altogether accounted for $59 \%$ of the total number of isolates. Prevalence of the Bacillus genus was seen chiefly in the first two sample collections (Figure 1). Bacillus pumilus was the most common species of the genus identified in this study, comprising $41.8 \%$ of the total Bacillus genus identified (data not shown).

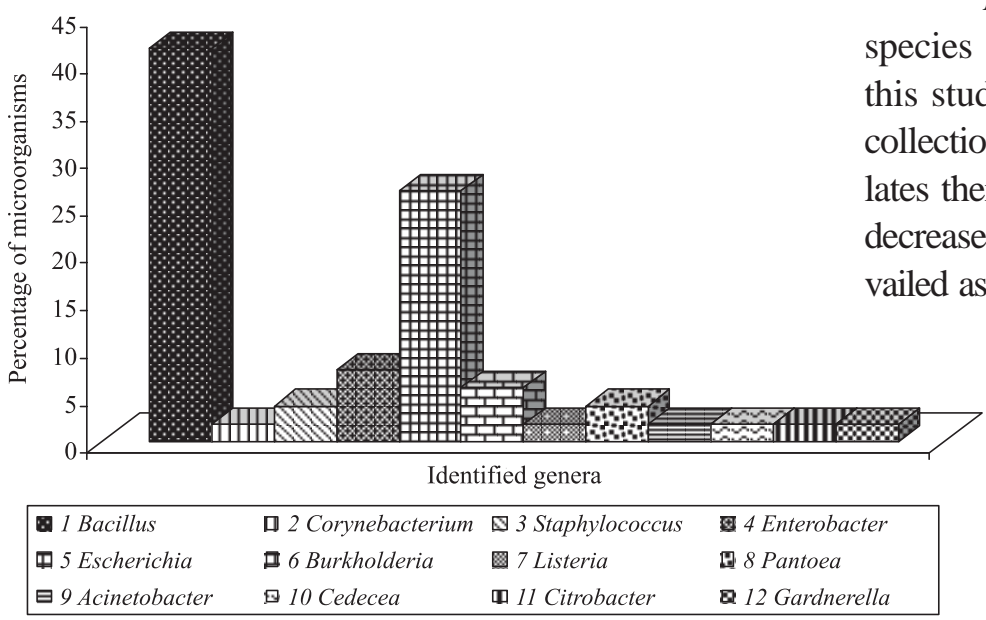

Figure 1. Total number of identified genera from sample collections 1 and 2 ( 15 and 30 days) respectively. $\mathrm{N}=53$. The genera are read from left to right on each line.
Escherichia coli is the bioindicator to establish the presence of fecal coliforms in a given sample. In Table 2 a slight rise can be seen in the coliform count measured for the fourth sample collection as compared with the second. This rise was confirmed by the identification of a greater number of $E$. coli isolates at the fourth sample collection, which accounted for $19.35 \%$ of the total number of isolates, as opposed to all other collections (Figures 1, 2, 3 and 4).

Since Enterobacter is one of the genera belonging to the total coliform group, its presence also works as an indication of a likely fecal contamination. Table 2 shows a slight increase in the total coliform counts for the third and six sample collections compared to the second. Figures 1, 2, and 3 indicate a general rise in the occurrence of Enterobacter isolates.

Pseudomonas pseudoalcaligenes was the only species of the Pseudomonas genus to be isolated in this study. Its presence was detected from the fourth collection on, with a gradual rise in the number of isoates thereafter (Figures 2, 3 and 4), accompanied by a in the occurrence of the other genera that prevailed as of the first sample collections (Figures 1 and 4).

The present study showed a great diversity for bacterial genera characterized in compost samples. The results indicate that no considerable oscillations occurred in this diversity apart from shifts in the prevalence of some genera throughout the process.

\section{PCR amplification}

Figure 5 and 6 show the amplification products of the compost samples inocu- 


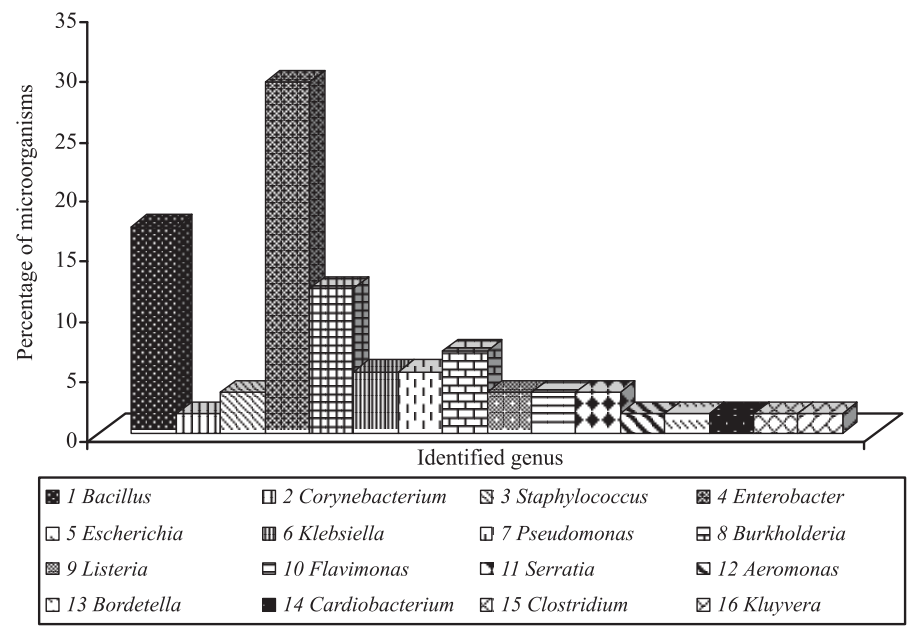

Figure 2. Total number of identified genera from sample collections 3 and 4 (45 and 60 days) respectively. $\mathrm{N}=58$. The genera are read from left to right on each line.

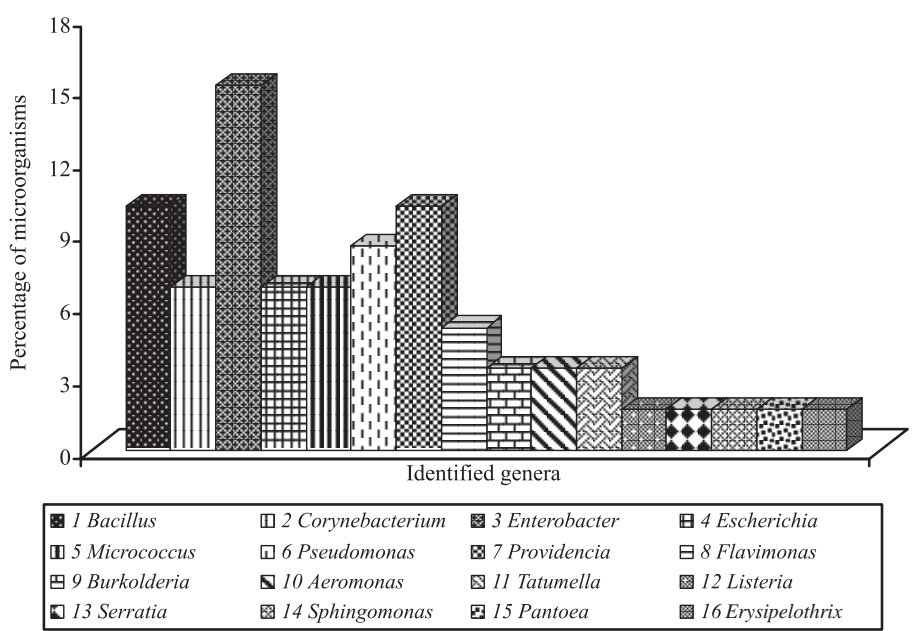

Figure 3. Total number of identified genera from sample collections 5 and 6 (60 and 75 days) respectively. $\mathrm{N}=59$. The genera are read from left to right on each line.

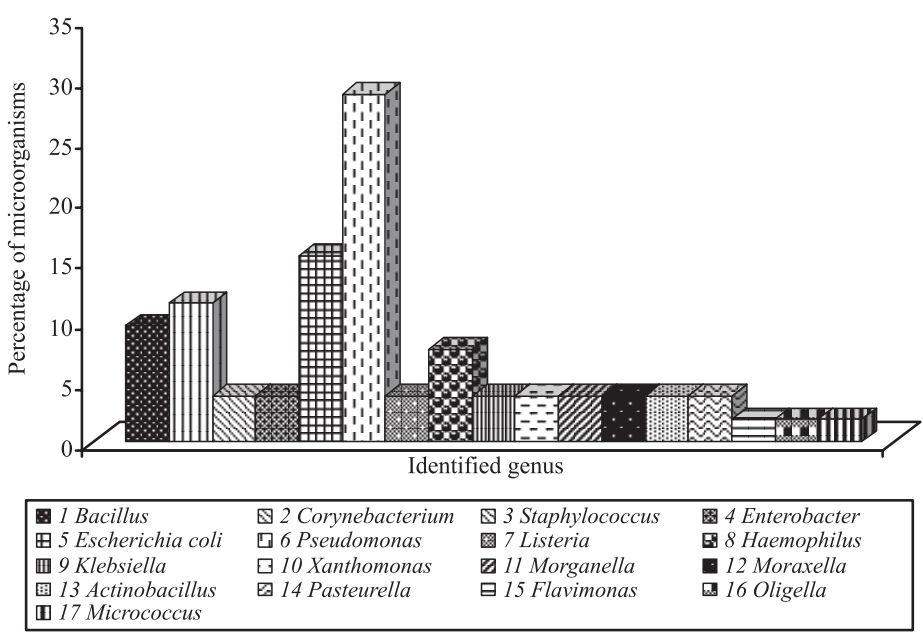

Figure 4. Total number of identified genera from sample collections 7 and 8 ( 90 and 154 days) respectively. $\mathrm{N}=52$. The genera are read from left to right on each line. lated and not inoculated with Escherichia coli (ETEC) when amplified with the primers LT10, LT11 and ST10, ST11 respectively.

Figure 5 shows the result obtained for the amplification of the LT gene, with a 221 bp product. The compost samples LTA1, LTA2, LTA3 were inoculated with $E$. coli (ETEC) and amplified the expected product. Two of the four compost samples (A1 and A2) that were not inoculated also amplified the same product even though the band was less intense.

Figure 6 shows the amplification product of the ST gene with a size of $167 \mathrm{bp}$. Three of the four compost samples inoculated with the $E$. coli (ETEC), STA1, STA2 and STA3, have amplified the fragment with the molecular weight of the target gene (167 bp). Likewise, for the four non-inoculated compost samples, A1, A2, A3 and A4, amplified fragments expected.

\section{DISCUSSION}

The $\mathrm{pH}$ values in composting process of domestic residue, usually starts with a more acidic $\mathrm{pH}$, that is the result of the initial metabolic activity of the bacteria population producing organic acids and carbon dioxide. Throughout the composting process, the elimination of carbon dioxide and the degradation of acids and proteins promotes the increase in $\mathrm{pH}$ values $[19,25]$. The $\mathrm{pH}$ results obtained in this study are in agreement with the results obtained by other workers [4,10].

In the initial stages of the composting process mesophilic bacteria are the main agents of biodegradation. Mesophilic bacteria are partly killed or inactivated at the outcome of the thermogenic phase, in which thermophilic and thermotolerant species such as fungi, some bacteria, and actinomycetes emerge. Average counts of heterotrophic bacteria in this work was similar to the counts found by Sidhu et al. [26] and Tiquia \& Tam [28].

A drop in coliforms counts is expected in composting process because of the sanitization of the process. In this work there 
was no fall in the number of total and fecal coliform counts, and comparable results had been found by other authors [15] with a decrease in fecal coliform from $2.0 \times 10^{7}$ to $3.1 \times 10^{3}$ cells/g. Such results point to the effectiveness of the composting process to produce a better final compost.

The drop in coliform counts for the waste under composting has been ascribed to the high temperatures in the thermophilic phase or to the loss of humidity from within the compost $[15,23]$ respectively. These authors also state that a simple reduction or even the whole elimination of fecal coliforms are not alone useful to establish the biological quality of composts, and point to the importance of an investigation for other

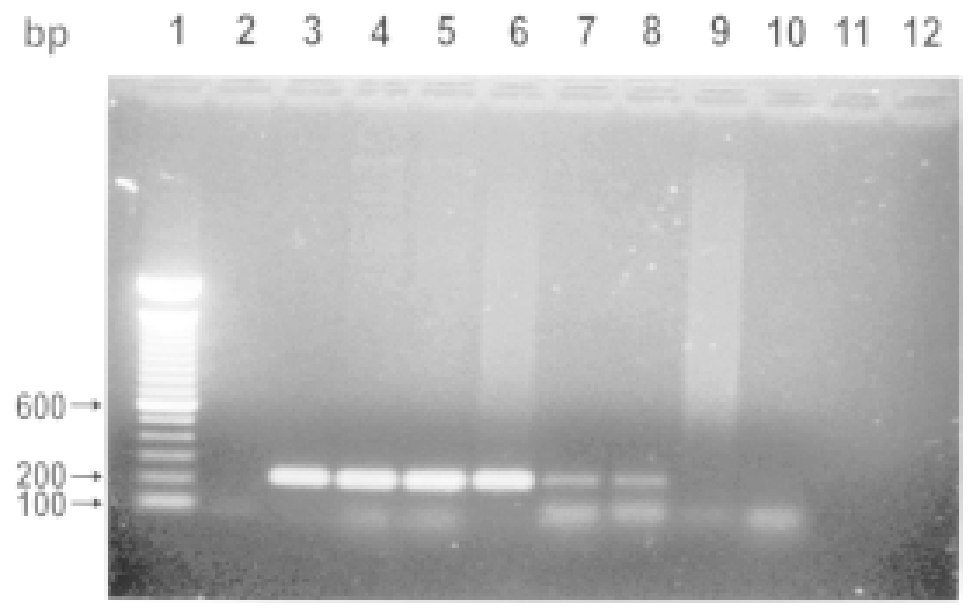

Figure 5. Agarose gel with the amplification products using LT10 and LT11 primers. Line (1): 100pb ladder; line (3): positive control - E. coli $\mathrm{LT}^{+}(\mathrm{LT} 1)$; lines (4-6): compost inoculated with $E$. coli LT $^{+}$(LTA1, LTA2, LTA3); lines (7-10): compost without inoculation (A1, A2, A3, A4); line (11): negative control of the reaction.

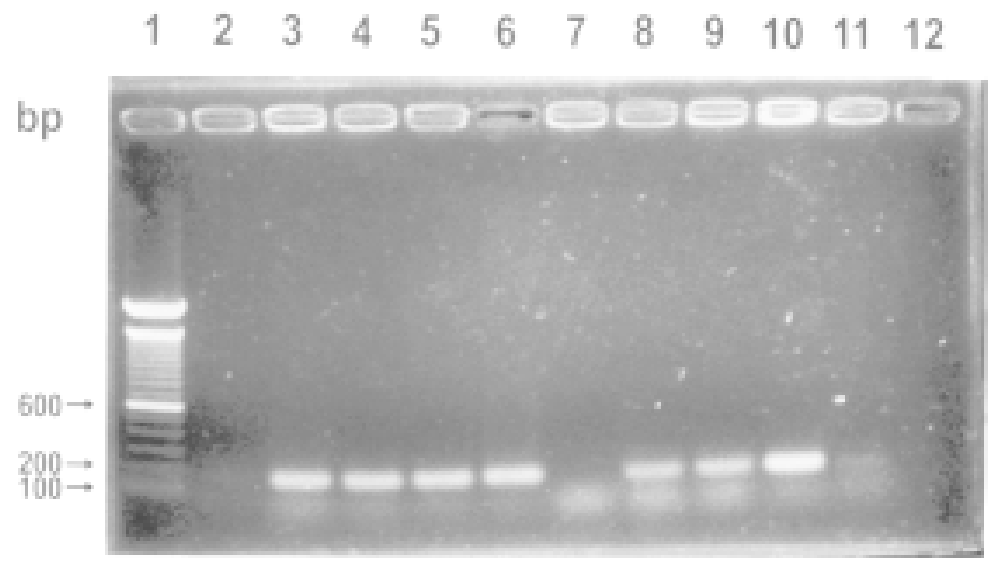

Figure 6. Agarose gel with the amplification products using ST10 and ST11 primers. Line (1): 100pb ladder; line (3): positive control - E. coli $\mathrm{ST}^{+}(\mathrm{ST} 1$ ); lines (4-6): compost inoculated with $E$. coli $\mathrm{ST}^{+}$(STA1, STA2, STA3); lines (7-11): compost without inoculation (A1, A2, A3, A4); line (12): negative control of the reaction. potentially pathogenic microorganisms that may be more resistant than the usual indicators detected in composting environments. Moreover, the full elimination of indicators from the compost is very difficult to accomplish [23]. On the other hand, some workers witnessed the complete elimination of coliforms even before the end of the first four weeks of composting $[10,28]$.

In this study, a recontamination with coliforms was observed, possibly due to the sprinkling of the compost with runoff waste slops for the control of temperature. This is a strong evidence that the whole process needs adjusting, with certain modifications in order to increase composting efficacy.

The classic biochemical identification techniques rendered possible the establishment of a profile for the bacterial community present in the windrow of municipal waste under composting.

Several of the genera identified in this study had likewise been frequently found in municipal wastes [10].

The Bacillus genus was the most common genus identified in this work. This had also been observed by Blanc et al. [5], and Dees \& Ghiorse [9] who stated that this prevalence happens due to the ability of the genus Bacillus to produce endospores which are extremely resistant to the high temperatures developed throughout the composting process.

The high presence of the Pseudomonas genus from the middle to the end of the process may be ascribed to a paucity of nutrients at the final phases of composting. Since this genus is metabolically very resourceful and has a high capacity to degrade renitent substances its presence in the final phases is expected $[8,30]$.

Results showed that the compost samples A 3 and A 4 did not amplify for the LT gene and that sample STA4 followed suit for the ST gene. These results may be ascribed to the presence of a substance acting as inhibitor for the reaction, which commonly happens in DNA investigations of natural environment samples $[1,21,27,31,32,35]$. Since the compost analyzed was the same, only the DNA extraction happened in different experimental systems. 
Results obtained for enterotoxigenic Escherichia coli in the samples of mature compost indicate that the PCR protocol is an important tool complementary to the classic biochemical assays that do not set apart species encoding or not virulence factors.
Acknowledgements. We thank the Brazilian government agency CAPES/PROF for the student's MS grant and the financial support to this study.

\section{SOURCES AND MANUFACTERS}

${ }^{1}$ Gibco BRL Life Technology. Rockville, Maryland, USA. ${ }^{2}$ Minicycler ${ }^{\mathrm{TM}}$ MJ Research. Watertown, Massachusetts, USA. ${ }^{3}$ Kodak Digital Science camera. Progama Kodak versão 35.2.

\section{REFERENCES}

1 Al-Soud W.A. \& Radström P. 1998. Capacity of nine thermostable DNA polymerase to mediate DNA amplification in the presence of PCR-inhibiting samples. Applied Environmental Microbiology. 64: 3748-3753.

2 APHA 1998. Standard methods for the examination of water and wastewater. 20th edn. New York: APHA, 1190p.

3 Bari Q.H. \& Koenig A. 2001. Effect of air recirculation and reuse on composting of organic solid waste. Resource, Conservation and Recycling. 33: 93-111.

4 Beffa T., Blanc M., Lyon P.F., Vogt G., Marchiani M., Fischer J.L. \& Aragno M. 1996. Isolation of Thermus strains from hot composts $\left(60\right.$ to $\left.80^{\circ} \mathrm{C}\right)$. Applied Environmental Microbiology. 62: 1723-1727.

5 Blanc M., Marilley L., Beffa T. \& Aragno M. 1999. Thermophilic bacterial communities in hot composts as revealed by most probable number counts and molecular (16s rDNA) methods. FEMS Microbiology Ecology. 28: 141-149.

6 Campbell S. 1995. Manual de compostagem para hortas e jardins: como aproveitar bem o resíduo orgânico doméstico. São Paulo: Nobel, 149p.

7 Clarke S.C. 2001. Diarrhoeagenic Escherichia coli - an emerging problem? Diagnostic Microbiology and Infectious Disease. 41: 93-98.

8 Cunha C.D. \& Leite S.G.S. 1997. Optimization of some environmental conditions to enhance gasoline biodegradation in soil microcosms bioaugmented with Pseudomonas putida. Revista de Microbiologia. 28: 129-134.

9 Dees P.M. \& Ghiorse W.C. 2001. Microbial diversity in hot synthetic compost as revealed by PCR-amplified rRNA sequences from cultivated isolated and extracted DNA. Microbiology Ecology. 35: 207-216.

10 Déportes I., Bendit-Guyod J.L., Zmirou D. \& Bouvier M.C. 1998. Microbial disinfection capacity of municipal solid waste (msw) composting. Journal of Applied. Microbiology. 85: 238-246.

11 Deus A.B.S. 1998. Viabilidade do uso da compostagem aeróbia para tratamento de resíduo em grandes centros urbanos. 125f. Monografia (Exame de Qualificação) - Programa de Pós-graduação em Recursos Hídricos e Saneamento, Instituto de Pesquisas Hidráulicas, Universidade Federal do Rio Grande do Sul.

12 Dwarakanath P., Visweswariah S.S., Subrahmanyam Y.V.B.K., Shanthi G., Jagannatha H.M. \& Balganesh T.S. 1989. Cloning and hyperexpression of a gene encoding the heat-stable toxin of Escherichia coli. Gene. 81: 219-226.

13 Gomez A. 1998. The evaluation of compost quality. Trends in Analytical Chemistry:17: 310 -314.

14 Hartilieb N., Marschner B. \& Klein W. 2001. Transformation of dissolved organic matter (dom) and ${ }^{14} \mathrm{C}$-labelled organic contaminants during composting of municipal biowaste. Science of The Total Environmental. 278: 1-10.

15 Hassen A., Belguith K., Jedidi N., Cherif A., Cherif M. \& Boudabous A. 2001. Microbial characterization during composting of municipal solid waste. Bioresource Technology. 80: 217-225.

16 Holt J.G., Krieg N.R., Sneath P.H.A., Staley J.T. \& Williams S.T. 1994. Bergey's Manual of Determinative Bacteriology. 9th edn. Baltimore: Williams \& Wilkins,787p.

17 Hue N.V. \& Liu J. 1995. Predicting compost stability. Compost Science and Utilization. 3: 8-15.

18 Innocenti F.D., Bellia G., Tosin M., Kapanen A. \& Itävaar A. 2001. Detection of toxicity realesed by biodegradable plastics after composting in activated vermiculite. Polymer Degradation Stability. 73: 101-106.

19 Jahnel M.C., Melloni R. \& Cardoso E.J.B. 1999. Maturidade de composto de resíduo urbano. Scientia Agricola. 56: 301-304.

20 Kiehl E.J. 1985. Fertilizantes orgânicos. São Paulo: Editora Agronômica Ceres Ltda., 429p.

21 Kreader C.A. 1996. Relief of amplification inhibition in PCR with bovine serum albumin or $\mathrm{T}_{4}$ gene 32 protein. Applied Environmental Microbiology. 62: 1102-1106.

22 Peters S., Koschinky S., Schwieger F. \& Tebbe C.C. 2000. Succession of microbial communities during hot composting as detected by PCR - single strand conformation polymorphism based genetic profiles of small - subunit rRNA genes. Applied Environmental Microbiology. 66: 930-936. 
23 Redlinger T., Graham J., Barud V.C. \& Avitia R. 2001. Survival of fecal coliforms in dry-composting toilets. Applied Environmental Microbiology. 67: 4036-4040.

24 Sambrook J., Fritsch E.F. \& Maniatis T. 1989. Molecular cloning: a laboratory manual. New York: Cold Spring Harbor Laboratory, 1355p.

25 Sharma V.K., Canditelli M., Fontoura F. \& Cornacchia G. 1997. Processing of urban and agro-industrial residues by aerobic composting: review. Energy Conversion. 38: 453-478.

26 Sidhu J., Gibbs R.A., Ho G.E. \& Unkovich I. 2001. The role of indigenous microorganisms in supression of Salmonella regrowth in composted biosolids. Water Research. 35: 913-920.

27 Tebbe C.C. \& Vahjen W. 1993. Interference of humic acids and DNA extracted directly from soil in detection and transformation of recombinant DNA from bacteria and a yeast. Applied Environmental Microbiology. 59: 2657-2665.

28 Tiquia S.M. \& Tam N.F.Y. 2000. Composting of spent pig litter and sludge with forced-aeration. Bioresource Technology. 72: 1-7.

29 Trubetskaya O.E., Trubetskoj O.A. \& Ciavatta C. 2001. Evaluation of the transformation of organic matter to humic substances in compost by coupling séc-page. Bioresource Technology. 77: 51-56.

30 Truffaut N., Mater D., Soulier S.H. \& Poupin P. 2001. Outils moléculaires d'évaluation dês capacités dégradatives de microflores de l'environnement. Bulletin de la Société Française de Microbiologie. 16: 190-196.

31 Tsai Y-L. \& Olson B.H. 1991. Rapid method for direct extraction of DNA from soil and sediments. Applied Environmental Microbiology. 57: 1070-1074.

32 Tsai Y-L., Palmer L.J. \& Sangermano L.R. 1993 Detection of Escherichia coli in sewage and sludge by polymerase chain reaction. Applied Environmental Microbiology. 59: 353-357.

33 Weppen P. 2001. Process calorimetry on composting of municipal organic wastes. Biomass Bioenergy. 21: 289-299.

34 Yamamoto T. \& Yokota T. 1983. Sequence of heat-labile enterotoxin of Escherichia coli pathogenic for humans. Journal of Bacteriology. 155: 728-733.

35 Yeates C., Gillings M.R., Davison A.D.,Altavilla N. \& Veal D.A. 1997. PCR amplification of crude microbial DNA extracted from soil. Letters Applied Microbiology. 25: 303-307. 